\title{
Oestrogen receptor $\beta$ is required for androgen-stimulated proliferation of LNCaP prostate cancer cells
}

\author{
Marcello Maggiolini, Anna Grazia Recchia, Amalia Carpino수, Adele Vivacqua, \\ Giovanna Fasanella, Vittoria Rago', Vincenzo Pezzi, Pierre-André Briand ${ }^{2}$, \\ Didier Picard ${ }^{2}$ and Sebastiano Andò ${ }^{1}$
}

Department of Pharmaco-Biology, University of Calabria, 87036 Rende (CS), Italy

${ }^{1}$ Department of Cellular Biology, University of Calabria, 87036 Rende (CS), Italy

${ }^{2}$ Département de Biologie Cellulaire, Université de Genève, Sciences III, CH-1211 Genève 4, Switzerland

(Requests for offprints should be addressed to Sebastiano Andò; Email: sebastiano.ando@ unical.it)

\begin{abstract}
The role of oestrogens in the development of prostate cancer is poorly understood. However, a large body of evidence has suggested that oestrogenic hormones may be involved in prostatic malignancy. The localization of oestrogen receptor $\beta$ (ER $\beta)$ in the secretory epithelium of the human prostate has raised the intriguing possibility that the action of oestrogen could be mediated, at least in part, by this receptor during the process of carcinogenesis. Hence, specific interference with oestrogen-activated and ER $\beta$-mediated transcriptional activity could open new issues in the endocrine manipulation of prostate tumours. In the present study, we provide new insights into the role of ER $\beta$ in the context of an androgen-responsive prostate cancer cell line such as LNCaP, which was used as a model system together with steroid receptor negative HeLa cells. ER $\beta$ and the mutated androgen receptor (AR) T877A did not discriminate between oestrogen- or androgen-induced transactivation, whereas ER $\beta$ and AR transcriptional activity were inhibited only by the respective hormone antagonists ICI 182,780 and casodex. Furthermore, the nuclear localization of ER $\beta$ evaluated by immunocytochemistry confirmed the promiscuous response to hormones in addition to the specific inhibitory action of antagonists. Interestingly, ICI 182,780 and an ER $\beta$ antisense expression vector repressed the growth effects of both $17 \beta$-oestradiol and $5 \alpha$-dihydrotestosterone, suggesting that ER $\beta$ has a key role in the proliferation induced by these steroids in LNCaP prostate cancer cells. Thus our findings implicate ER $\beta$ as a potential target for the treatment of prostate tumours.
\end{abstract}

Journal of Molecular Endocrinology (2004) 32, 777-791

\section{Introduction}

Epidemiological and experimental studies have suggested that oestrogenic hormones are involved in prostatic malignancy (Taplin \& Ho 2001, Weihua et al. 2001, and references therein), although their action remains to be completely understood. In a variety of mammals, including humans, pharmacological doses of oestrogens may induce proliferative alteration of the prostatic epithelium such as squamous metaplasia (Mawhinney \& Neubauer 1979, Levine et al. 1991), and similar effects can also be promoted by oestrogens in the regressed prostates of hypophysectomized or castrated dogs (Leav et al. 1978, Merk et al. 1986).

It has been demonstrated that the effects of oestrogens on target tissues are mediated by the oestrogen receptors $\alpha$ and $\beta$ (ER $\alpha$ and $E R \beta)$, which are ligand-inducible transcription factors (Kuiper et al. 1996). They present 10-15\% homology in the N-terminal region, more than 90\% homology in the DNA-binding domain and more than $60 \%$ homology in the ligand-binding domain, and share similar ligand-binding affinities (Mosselman et al. 1996). Both receptors are distributed in many of 
the same organs; however, a distinct tissue and cell type localization, together with different levels of expression, have been reported (Enmark et al. 1997, Kuiper et al. 1997). For instance, in the prostate, $\mathrm{ER} \alpha$ was localized in normal and malignant stroma (Schulze \& Claus 1990, Brolin et al. 1992, Ehara et al. 1995), whereas $\operatorname{ER} \beta$ was found to exhibit a progressive loss of expression in the secretory epithelium after the process of carcinogenesis (Horvath et al. 2001, Leav et al. 2001). ER-mediated gene expression (Carruba et al. 1994, Castagnetta et al. 1995, Lau et al. 2000) and cross-talk between ERs and other steroid receptors that trigger non-genomic proliferative pathways (Migliaccio et al. 2000, and references therein) have been demonstrated in several human prostate cancer cell lines. Interestingly, in our and other studies (Lau et al. 2000, Migliaccio et al. 2000, Maggiolini et al. 2002), the pure oestrogen antagonist ICI 182,780 inhibited the proliferation of human prostate cancer cells expressing ER $\beta$. However, the mechanisms of action of oestrogens and antioestrogens in this system have not been fully clarified.

Herein, we provide new insights into the role of $\operatorname{ER} \beta$ in the context of an androgen-responsive prostate cancer cell line, LNCaP, which was used as a model system together with steroid receptor negative HeLa cells. We demonstrate that $\mathrm{ER} \beta$ and the mutated androgen receptor (AR) T877A do not discriminate between oestrogens or androgens in mediating transcription, whereas they are inhibited only by the respective hormone antagonists, ICI 182,780 and casodex. Most notably, ICI 182,780 and an ER $\beta$ antisense expression vector reverse the proliferative effects of both $17 \beta$-oestradiol (E2) and $5 \alpha$-dihydrotestosterone (DHT), demonstrating that $\mathrm{ER} \beta$ is involved in the growth response to these hormones in LNCaP prostate cancer cells.

\section{Materials and methods}

\section{Reagents}

DHT and E2 were purchased from Sigma (Italy), ICI 182,780 was purchased from Tocris Northpoint (UK), casodex was a gift from Astra-Zeneca (Italy), and Src inhibitor PP2 was purchased from Calbiochem (Italy).

\section{Plasmids}

Firefly luciferase reporter plasmids used were: XG46TL (Bunone et al. 1996) for the AR, GK1 for the Gal4 fusion protein Gal93ER $\beta$ (Maggiolini et al. 2001), and XETL (Maggiolini et al. 2001), pS2 $\mathrm{ERE}$ and $\mathrm{pS} 2 \Delta \mathrm{ERE}$ (both gifts from V. Giguère, Montreal, Canada) for ER $\beta$. pS2 ERE contains the $\sim 1050$ bp pS2 promoter and PGR mutagenesis yielded the oestrogen response element (ERE) deletion construct, pS2 $\mathrm{ERE}$ (Tremblay et al. 1997). The AR mutant T877A (a gift from F.S. French, Chapel Hill, NC, USA) was constructed by a two-step PCR method replacing the HindIII/ BamHI fragment from the wild type in pCMVhAR (Tan et al. 1997). The renilla luciferase expression vector pRL-TK (Promega) was used as a transfection standard. The ER $\beta$ antisense plasmid contains, in reverse orientation, a $1170 \mathrm{bp}$ fragment of the coding sequences of the human ER $\beta$ in the pIRESpuro2 vector (Clontech).

\section{Cell culture}

Human prostate cancer LNCaP cells (a gift from R. Baserga, Philadelphia, USA) were grown in RPMI 1640 medium without phenol red and supplemented with L-glutamine $(2 \mathrm{mM})$, penicillin $(100 \mathrm{U} / \mathrm{ml})$, streptomycin $(100 \mathrm{U} / \mathrm{ml})$ and $10 \%$ fetal calf serum (FCS). HeLa cells were maintained in Dulbecco's modified Eagle's medium (DMEM) without phenol red and supplemented with L-glutamine $(2 \mathrm{mM})$, penicillin $(100 \mathrm{U} / \mathrm{ml})$, streptomycin $(100 \mathrm{U} / \mathrm{ml})$ and $10 \%$ FCS. Cells to be processed for immunoblotting and immunocytochemical staining were switched to medium without serum 1 and 3 days before treatments, respectively (see also Results).

\section{Transfections and luciferase assays}

Cells were transferred into 24-well plates with $500 \mu \mathrm{l}$ regular growth medium/well the day before transfection. The medium was replaced with RPMI or DMEM lacking phenol red in addition to serum on the day of transfection, which was performed using the Fugene6 Reagent as recommended by the manufacturer (Roche Diagnostics), with a mixture containing $0.5 \mu \mathrm{g}$ reporter plasmid, $2 \mathrm{ng}$ $\mathrm{pRL}-\mathrm{TK}$ and $0 \cdot 2 \mu \mathrm{g}$ plasmids expressing the AR or ER (where applicable). After 5-6 h, the medium was replaced with RPMI or DMEM lacking phenol red and supplemented with $1 \%$ charcoal stripped FCS; ligands were added at this point, and cells were incubated for $24 \mathrm{~h}$. Luciferase activity was 
then measured with the Dual Luciferase Kit (Promega) according to the manufacturer's recommendations. Firefly luciferase activity was normalized to the internal transfection control provided by the renilla luciferase activity.

\section{Immunocytochemical staining}

Cultured LNCaP cells were fixed in fresh paraformaldehyde (2\% for $30 \mathrm{~min}$ ). After removal of the paraformaldehyde, hydrogen peroxide $(3 \%$ in methanol for $30 \mathrm{~min}$ ) was used to inhibit endogenous peroxidase activity. Cells were then incubated with normal horse serum $(10 \%$ for $30 \mathrm{~min}$ ) to block the non-specific binding sites. Immunocytochemical staining was performed using a mouse monoclonal IgG primary antibody (Serotec, Oxford, UK) generated against the C-terminus of the human $\operatorname{ER} \beta$ (1:50 overnight at $\left.4{ }^{\circ} \mathrm{C}\right)$. A biotinylated horse antimouse $\operatorname{IgG}(1: 600)$ was applied for $60 \mathrm{~min}$ at room temperature, as the secondary antibody (Vector Laboratories, Burlingame, California, USA). Subsequently, antibody bindings were visualized by using the avidin-biotin-horseradish peroxidase complex (Vector Laboratories, Burlingame, California, USA) (1:100 for $30 \mathrm{~min}$ at room temperature) and 3,3'-diaminobenzidine tetrachloride dihydrate (Vector Laboratories) was used as detection system. After each step, cells were rinsed with Tris buffer saline $(0.05 \mathrm{M}$ Tris-HCl plus $0.15 \mathrm{M} \mathrm{NaCl}, \mathrm{pH}$ $7 \cdot 6$ ) containing $0 \cdot 05 \%$ Triton-X100. In control experiments, cells were processed, replacing the primary antibody with mouse serum (Dako) or by using a primary antibody pre-absorbed $(48 \mathrm{~h}$ at $4{ }^{\circ} \mathrm{C}$ ) with an excess of purified $\operatorname{ER} \beta$ protein (M-Medical, Milan, Italy).

\section{Immunoblotting}

LNCaP cells were grown in $10 \mathrm{~cm}$ dishes and exposed to ligands for $24 \mathrm{~h}$ before lysis in $500 \mu \mathrm{l}$ 50 mM HEPES (pH 7.5), $150 \mathrm{mM} \mathrm{NaCl}, 1.5 \mathrm{mM}$ $\mathrm{MgCl}_{2}, 1 \mathrm{mM}$ EGTA, 10\% glycerol, 1\% Triton $\mathrm{X}-100,1 \%$ SDS, and a mixture of protease inhibitors containing $1 \mathrm{mM}$ aprotinin, $20 \mathrm{mM}$ phenyl methylsulphonyl fluoride and $0.2 \mathrm{M}$ sodium-orthovanadate. Equal amounts of wholeprotein extract were resolved on a 10\% SDSpolyacrylamide gel. Proteins were transferred to a nitrocellulose membrane, probed with the antibodies against ER $\beta$ (Serotec), AR and $\beta$-actin (both from Santa Cruz Biotechnology, Santa Cruz, California, USA), and revealed using the ECL System (Amersham).

\section{Proliferation assays}

For quantitative proliferation assays, $1 \times 10^{4}$ LNCaP cells were seeded in 24-well plates in regular growth medium. Once they had attached, cells were washed, transfected with $500 \mathrm{ng} /$ well $\mathrm{ER} \beta$ antisense where applicable and incubated in medium without serum for $24 \mathrm{~h}$. The next day the medium was changed and supplemented with $1 \%$ charcoal-stripped FCS. Ligands were added at this point; thereafter, medium was changed every day and treatments were renewed. On day 5 (after 3 days of treatment), cells were trypsinized and counted in a haemocytometer using the trypan blue exclusion method.

\section{Statistical analysis}

Statistical analysis was performed using analysis of variance followed by Newman-Keuls testing to determine differences in means. $P$ values $<0.05$ were considered significant.

\section{Results}

\section{ERß and AR mutant T877A are cross-activated by E2 and DHT but not cross-inhibited by antihormones}

The mutant AR T877A is expressed together with $\mathrm{ER} \beta$, but not ER $\alpha$, in LNCaP human prostate cancer cells (Lau et al. 2000), which have been used as a model for the androgen-sensitivity of prostate tumours (Webber et al. 1997). The mutation T877A influences the ligand-binding specificity of AR (Sack et al. 2001), allowing its transactivation by a variety of compounds including androgen antagonists and oestrogens (Elo et al. 1995, Kemppainen \& Wilson 1996, Tan et al. 1997, Grigoryev et al. 2000, Maggiolini et al. 2002). As for ER $\beta$, there are no available data regarding the transactivating properties of the natural ligand E2 or other steroids in the context of prostate cancer cell lines. Thus, as an initial step toward elucidating the transcriptional capability of ER $\beta$, we transiently transfected LNCaP cells with the ER reporter plasmid, XETL, 
which carries the firefly luciferase coding sequences under the control of an ERE upstream of the thymidine kinase promoter. Likewise, cells were cotransfected with the expression vector of renilla luciferase to provide an internal control and, in most experiments as indicated, with a plasmid encoding $\operatorname{ER} \beta$ to boost the response of the endogenous receptor (Fig. 1). Luciferase activity of cells receiving vehicle was set as onefold induction, upon which the results of treatments were calculated.

Figure 1 shows that the endogenous and transfected ER $\beta$ were able to respond to both E2 and DHT, and that activation was inhibited by the oestrogen antagonist ICI 182,780 but not by the androgen antagonist casodex or the Src inhibitor PP2. Next, we investigated whether $\operatorname{ER} \beta$ could induce the transcriptional activity of an EREcontaining natural promoter such as the pS2 promoter (Berry et al. 1989). Figure 2 demonstrates that E2 and DHT induced an efficient receptor transactivation, again reversed only by the antioestrogen ICI 182,780. The response was clearly mediated by the ER, as deletion of the ERE abolished the response to both hormones (Fig. 2B). Results similar to those with DHT were also obtained using the synthetic androgen, R1881 (data not shown).

To assess the potential of E2 and DHT, and of antihormones, for modulating transcription via $\mathrm{AR}$, we transiently transfected LNCaP cells with the reporter plasmid, XG46TL, which carries firefly luciferase sequences under the control of an androgen response element (ARE) upstream of the thymidine kinase promoter. Figure 3 reveals that E2 and DHT were direct AR inducers, as the transactivation was inhibited by the androgen antagonist casodex but not by the oestrogen antagonist ICI 182,780 or the Src inhibitor PP2. Thus E2 and DHT are cross-activators of ER $\beta$ and the AR mutant T877A expressed in LNCaP cells, whereas ICI 182,780 and casodex inhibit the transactivation of such receptors in a specific manner.

To provide further evidence that $\mathrm{ER} \beta$ is directly activated by $\mathrm{E} 2$ and DHT, the reporter plasmids XETL and pS2 ERE were transfected together with the $\operatorname{ER} \beta$ expression vector in steroid receptor negative HeLa cells (Fig. 4A). The results were similar to those obtained in LNCaP cells, confirming the potential effect of hormones and antagonists on ER $\beta$-mediated transcriptional activity. Nuclear receptors such as ERs contain two main transcription activation functions $(\mathrm{AF})$ : the $\mathrm{N}$-terminal AF1 and the C-terminal, hormone binding domain (HBD)-associated AF2, which is known to be agonist dependent (Kumar et al. 1987). A chimeric protein consisting of the heterologous DNA binding domain of the yeast transcription factor Gal4 and the ER $\beta$-HBD was able to respond to E2 and DHT in a transient expression assay (Fig. 4B). Also in this context, transcription was inhibited by ICI 182,780 but was not influenced by casodex (Fig. 4B).

Finally, using HeLa cells we verified the ability of DHT and E2 to transactivate directly the AR mutant T877A that was specifically inhibited by casodex (Fig. 4G). In agreement with the findings of a previous study (Panet-Raymond et al. 2000), coexpression of $\mathrm{AR}$ and $\mathrm{ER} \beta$ resulted in no significant change in receptor activation by either oestrogen or androgen (data not shown).

\section{E2 and DHT induce nuclear localization of ERß in LNCaP cells}

The genomic actions of steroid hormones are mediated by steroid receptors, which in their unliganded form reside associated with molecular chaperones in the cytoplasm, the nuclear compartment, or both (Beato et al. 1995, Pratt \& Toft 1997). For ER $\alpha$, mainly localized in the nucleus even in the absence of hormone, ligand binding leads to conformational changes that result in receptor activation and transcriptional regulation of target genes (Tsai \& O’Malley 1994).

To provide evidence that E2 and DHT are able to induce the nuclear localization of the activated endogenous ER $\beta$ expressed in LNCaP cells, we analysed its subcellular distribution by immunocytochemistry after a short $(1 \mathrm{~h})$ treatment with ligands.

ER $\beta$ antibodies are now available from a number of commercial and private sources; however, considerable variability in specificity and sensitivity has been reported among the results of different studies (Skliris et al. 2002, and references therein). To verify the specificity of the antibody used (see Materials and methods), we transfected the steroid-receptor negative HeLa cells with an expression plasmid encoding ER $\beta$, which revealed a strong nuclear immunodetection not observed in 


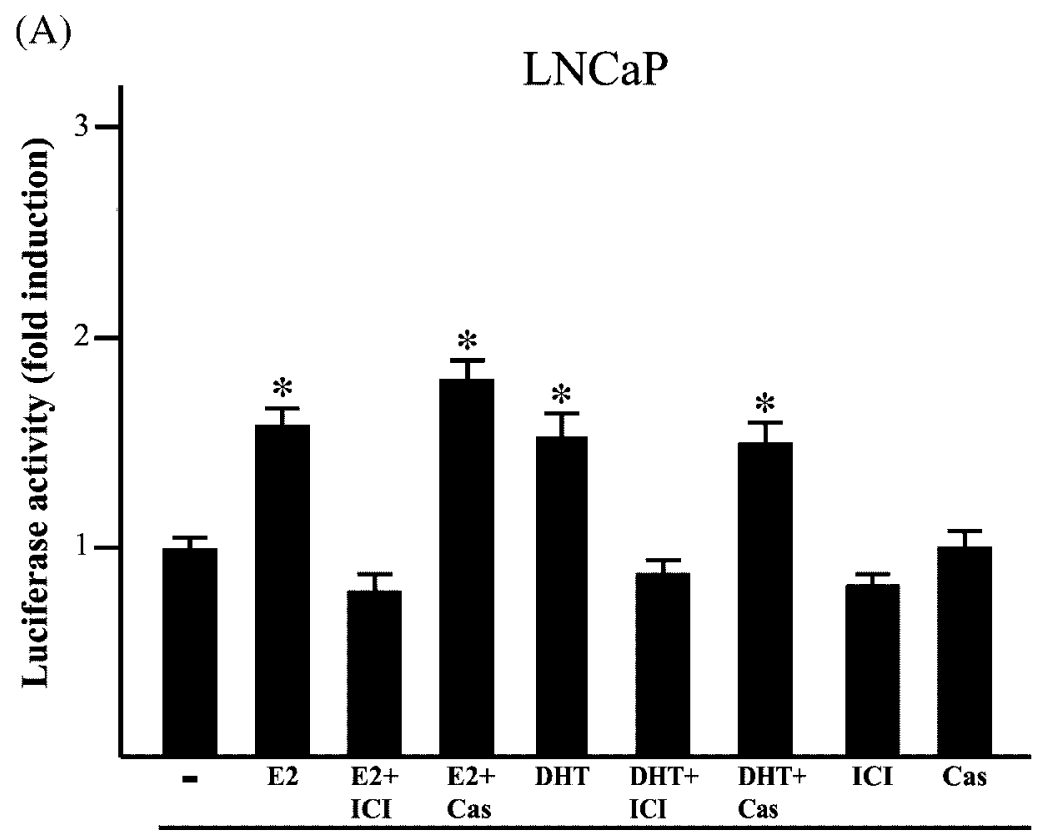

XETL

(B)

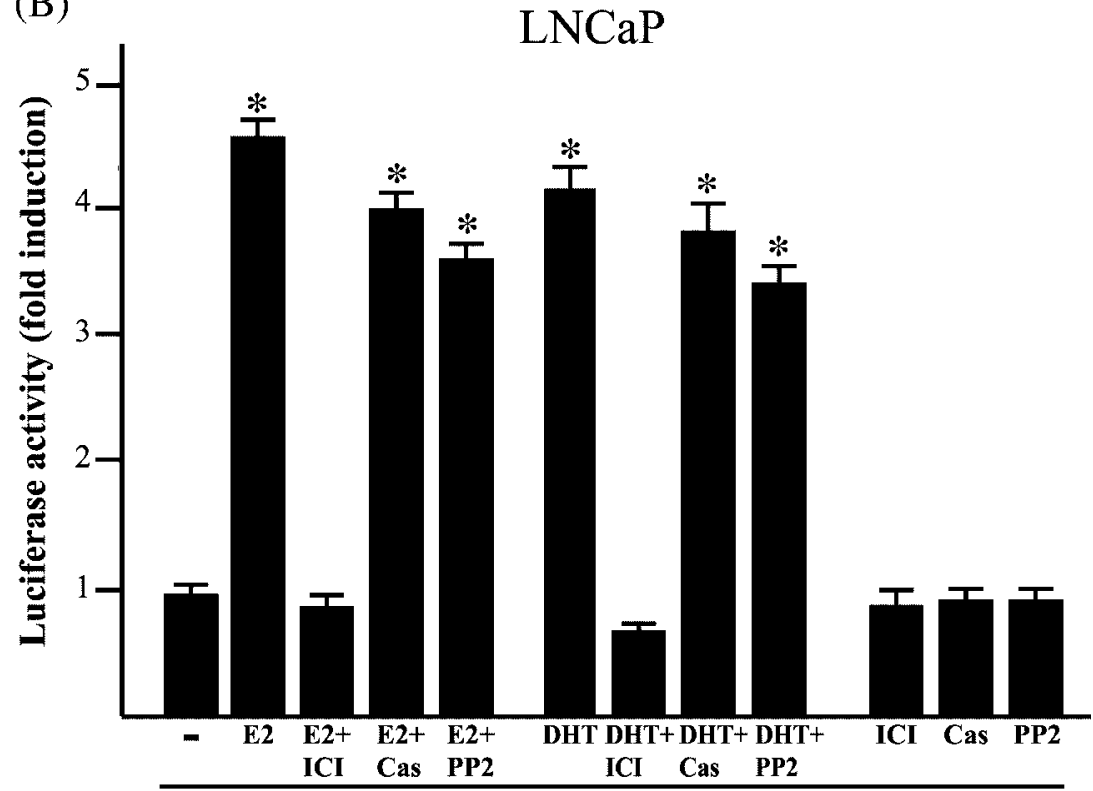

XETL + ER $\beta$

Figure 1 The activation of ER $\beta$ by E2 and DHT in LNCaP cells is inhibited only by ICI 182,780 (ICl). (A) The reporter plasmid XETL was transfected to evaluate the response of endogenous ER $\beta$ after a $24 \mathrm{~h}$ exposure to $10 \mathrm{nM}$ E2 and DHT and $1 \mu \mathrm{M} \mathrm{ICl} \mathrm{182,780} \mathrm{and} \mathrm{casodex} \mathrm{(Cas).} \mathrm{Luciferase} \mathrm{activity} \mathrm{of} \mathrm{cells} \mathrm{receiving} \mathrm{ethanol} \mathrm{alone} \mathrm{(-)} \mathrm{was} \mathrm{set} \mathrm{as}$ onefold induction, upon which treatments were calculated. (B) The response to hormones and antagonists was assayed as in (A), except that XETL was co-transfected with an expression plasmid encoding ER $\beta$. The Src inhibitor PP2 was used at a concentration $5 \mu \mathrm{M}$. Each data point represents the mean \pm S.D. of three independent experiments performed in triplicate. ${ }^{*} P<0.05$ compared with ethanol alone $(-)$. 


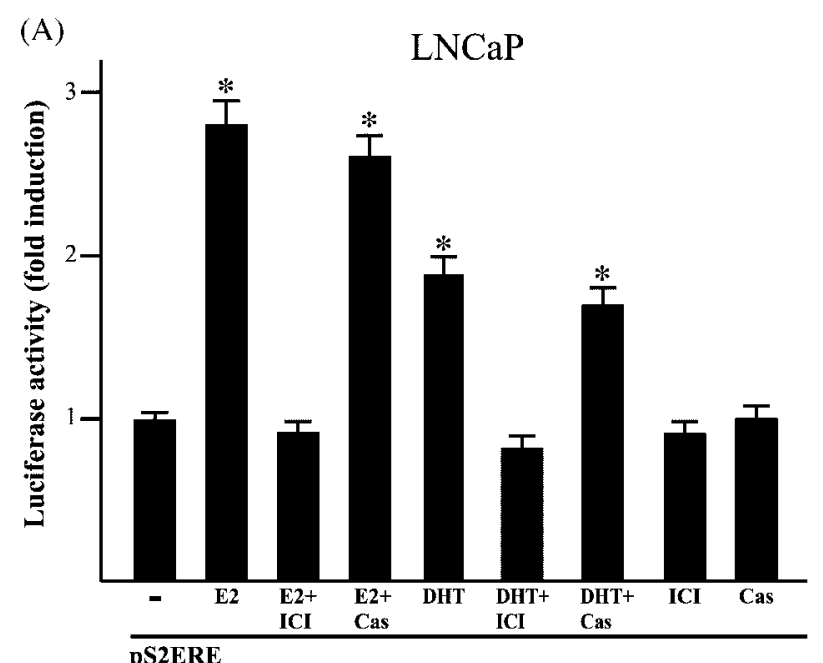

(B)

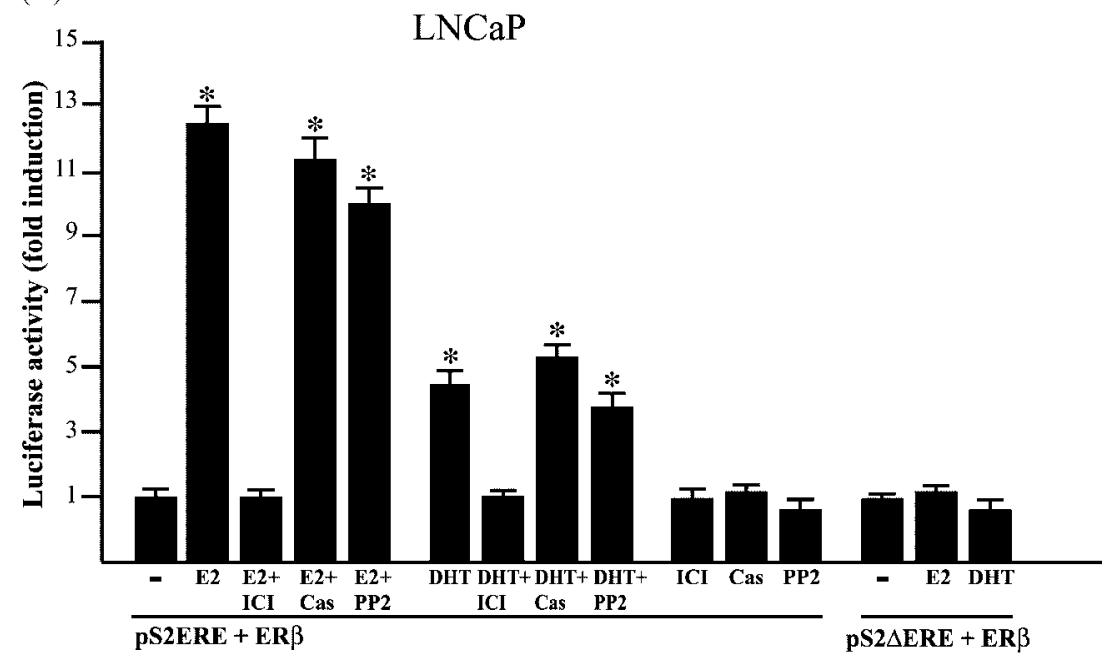

Figure 2 The ERE sequence is required for the activation of ER $\beta$ by E2 and DHT in LNCaP cells. (A) An intact pS2 promoter (pS2 ERE) was transfected to evaluate the response of endogenous ER $\beta$ after a $24 \mathrm{~h}$ exposure to $10 \mathrm{nM}$ E2 and DHT and $1 \mu \mathrm{M} \mathrm{ICI} \mathrm{182,780} \mathrm{and} \mathrm{casodex} \mathrm{(Cas).} \mathrm{Luciferase} \mathrm{activity} \mathrm{of}$ cells receiving ethanol alone (-) was set as onefold induction, upon which treatments were calculated. (B) The response to hormones, antagonists and the Src inhibitor PP2 was assayed as in (A), except that the reporter gene pS2 ERE or the deleted pS2 promoter without ERE (pS2 $\triangle E R E)$ were co-transfected with an expression plasmid encoding ER $\beta$. Each data point represents the mean \pm S.D. of three independent experiments performed in triplicate. ${ }^{*} P<0.05$ compared with ethanol alone $(-)$.

cells transfected with the vector alone (Fig. 5A). Then we turned to the LNCaP cells, which required 3 days of serum deprivation in order to achieve complete abolition of detectable ER $\beta$ immunoreactivity (Fig. 5B; see comments below). This basal condition was essential to reveal the hormone-specific activity. In fact, the addition of E2 or DHT produced a strong staining intensity exclusively in the nuclear compartment, as demonstrated by the representative immunoreactions in Fig. 5B. In contrast, no signals were observed either when the anti-ER $\beta$ antibody was 


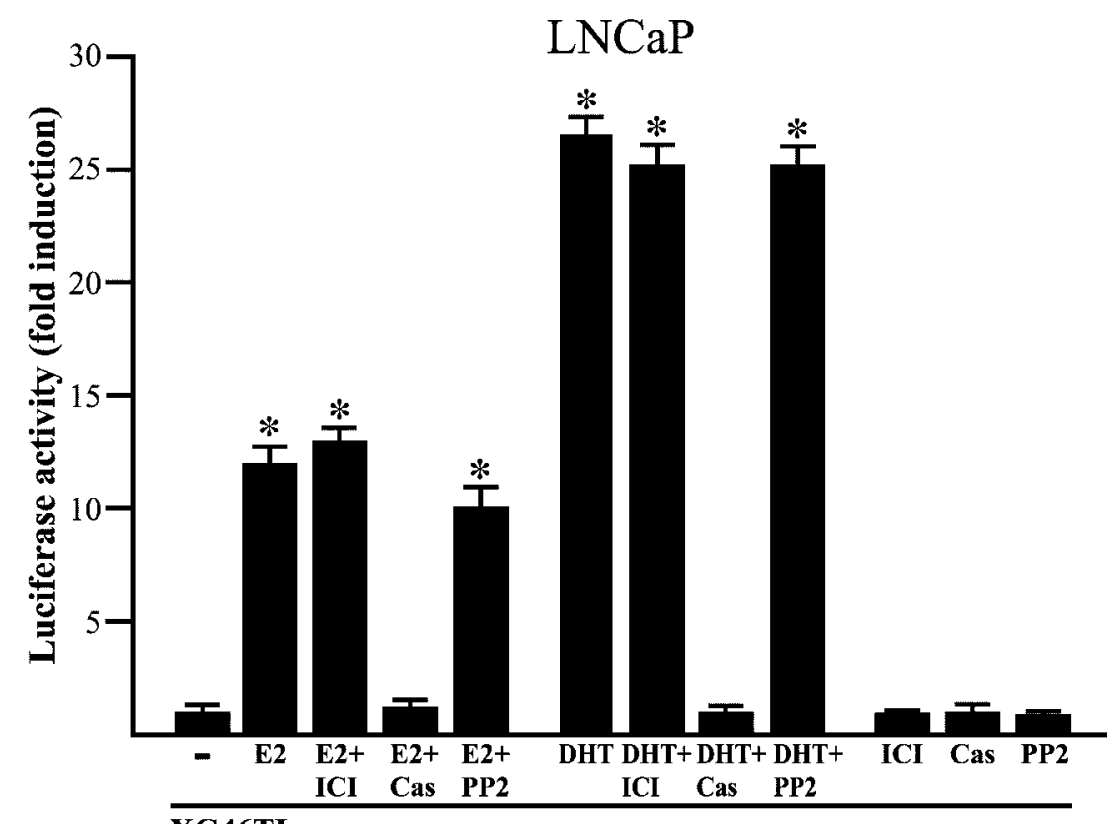

XG46TL

Figure 3 The activation of AR mutant T877A by E2 and DHT is inhibited only by casodex (Cas) in LNCaP cells. Transfections were performed with the reporter gene XG46TL to evaluate the response of the AR mutant T877A after a $24 \mathrm{~h}$ exposure to $10 \mathrm{nM}$ E2 and DHT, $1 \mu \mathrm{M} \mathrm{ICl} 182,780$ and Cas and $5 \mu \mathrm{M}$ Src inhibitor PP2. Luciferase activity of cells receiving ethanol alone (-) was set as onefold induction, upon which treatments were calculated. Each data point represents the mean \pm S.D. of three independent experiments performed in triplicate. ${ }^{\star} P<0.05$ compared with ethanol alone $(-)$.

replaced by irrelevant mouse $\operatorname{IgG}$ or when the primary antibody preabsorbed with an excess of receptor protein (data not shown). Interestingly, ICI 182,780, but not casodex, reversed the immunoreactive signals elicited by both hormones in accordance with their ability to transactivate $\mathrm{ER} \beta$ in a direct manner (Fig. 5B).

\section{Expression of ERß is up-regulated by E2 and DHT in LNCaP cells}

In view of the ability of $\mathrm{E} 2$ and DHT to induce the nuclear accumulation and the transcriptional activity of $\operatorname{ER} \beta$, we aimed to examine the effects of hormones on the expression of $\operatorname{ER} \beta$ protein in LNCaP cells. Figure 6 shows that a $24 \mathrm{~h}$ exposure to either steroid significantly enhanced the protein content of endogenous ER $\beta$. It is of note that, in the immunocytochemistry assay, the basal ER $\beta$ signal was silenced only after 3 days of serumdeprived conditions. The ER $\beta$ up-regulation by agonists observed in the present investigation and in a recent study (Power \& Thompson 2003) parallels that of the AR mutant T877A that resulted from the stabilization of the ligandreceptor complex (Krongard et al. 1991, Zhou et al. 1995, Yeap et al. 1999, Maggiolini et al. 2002), and further correlates the activity of both receptors in LNCaP cells. Likewise, an increased expression of $\mathrm{ER} \alpha$ in response to $\mathrm{E} 2$ has been reported in Ishikawa endometrial carcinoma cells (Robertson et al. 2002), whereas it has largely been demonstrated that $\mathrm{ER} \alpha$ is down-regulated by agonists in breast cancer cells (Santagati et al. 1997, Maggiolini et al. 1999, 2001).

\section{ICI 182,780, casodex and ER $\beta$ antisense block the E2- and DHT-induced proliferation of LNCaP cells}

Having established that DHT and E2 are cross-agonists for both the AR mutant T877A and ER $\beta$ whereas casodex and ICI 182,780 are specific androgen and oestrogen antagonists, 

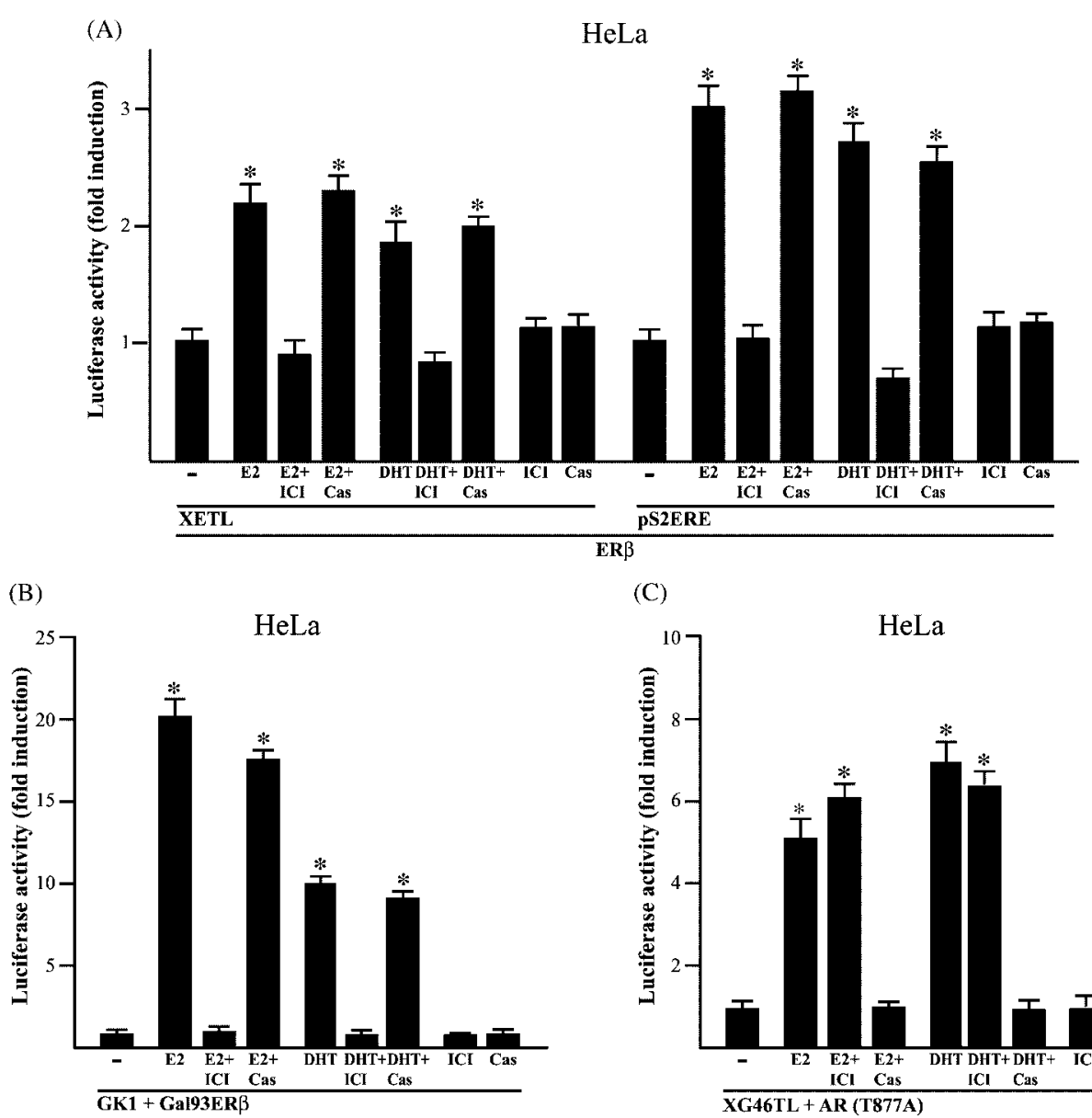

(C)

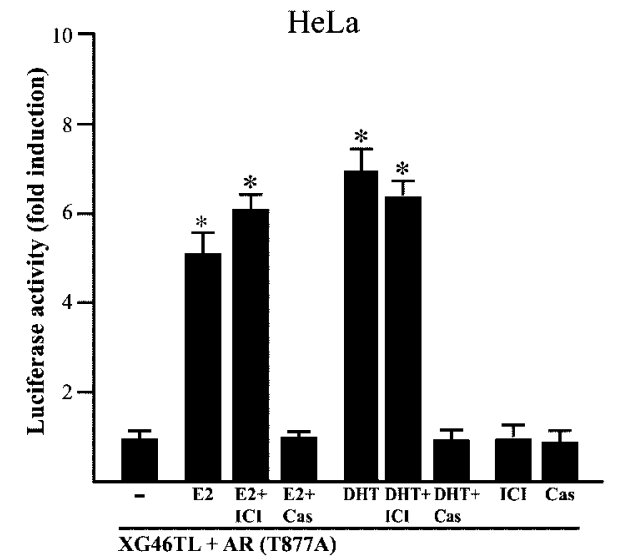

Figure $4 \mathrm{E} 2$ and DHT are agonists for both $\mathrm{ER} \beta$ and AR (T877A), whereas ICI 182,780 and casodex (Cas) are specific antagonists in HeLa cells. (A) The reporter plasmids XETL or pS2 ERE were co-transfected with an expression plasmid encoding ER $\beta$ to evaluate the response of a $24 \mathrm{~h}$ exposure to $10 \mathrm{nM}$ E2 and DHT and $1 \mu \mathrm{M} \mathrm{ICl} \mathrm{182,780} \mathrm{and} \mathrm{Cas.}$ Luciferase activity of cells receiving ethanol alone $(-)$ was set as onefold induction, upon which treatments were calculated. (B) The Gal4 reporter gene GK1 and the fusion protein Gal93ER $\beta$, consisting of the Gal4 DNA binding domain and the ER $\beta$ hormone binding domain, were co-transfected to evaluate the response of hormones and antagonists as in (A). (C) The reporter gene XG46TL and the AR mutant T877A were co-transfected to evaluate the response of hormones and antagonists as in (A). Each data point represents the mean \pm S.D. of three independent experiments performed in triplicate. ${ }^{\star} P<0.05$ compared with ethanol alone (-) for same reporter plasmid.

respectively, we attempted to evaluate the physiological interplay of hormones and antihormones in a complex response such as cell proliferation. Hence, we treated LNCaP cells with $10 \mathrm{nM}$ DHT or $\mathrm{E} 2$ in combination with $1 \mu \mathrm{M}$ casodex or ICI 182,780. Medium and treatments were renewed every day for 3 days and then cells were trypsinized and counted. The growth response was then expressed as percentage of cells after treatments in respect to those treated with ethanol used in the same volume as for compounds tested (Fig. 7A). Both DHT and E2 significantly stimulated cell proliferation, correlating with their ability to activate the AR mutant T877A. Interestingly, cell growth promoted by hormones was inhibited by either casodex or ICI 182,780. Note that only ICI 182,780 functions as an $\operatorname{ER} \beta$ antagonist in transactivation assays. The repression of LNCaP 


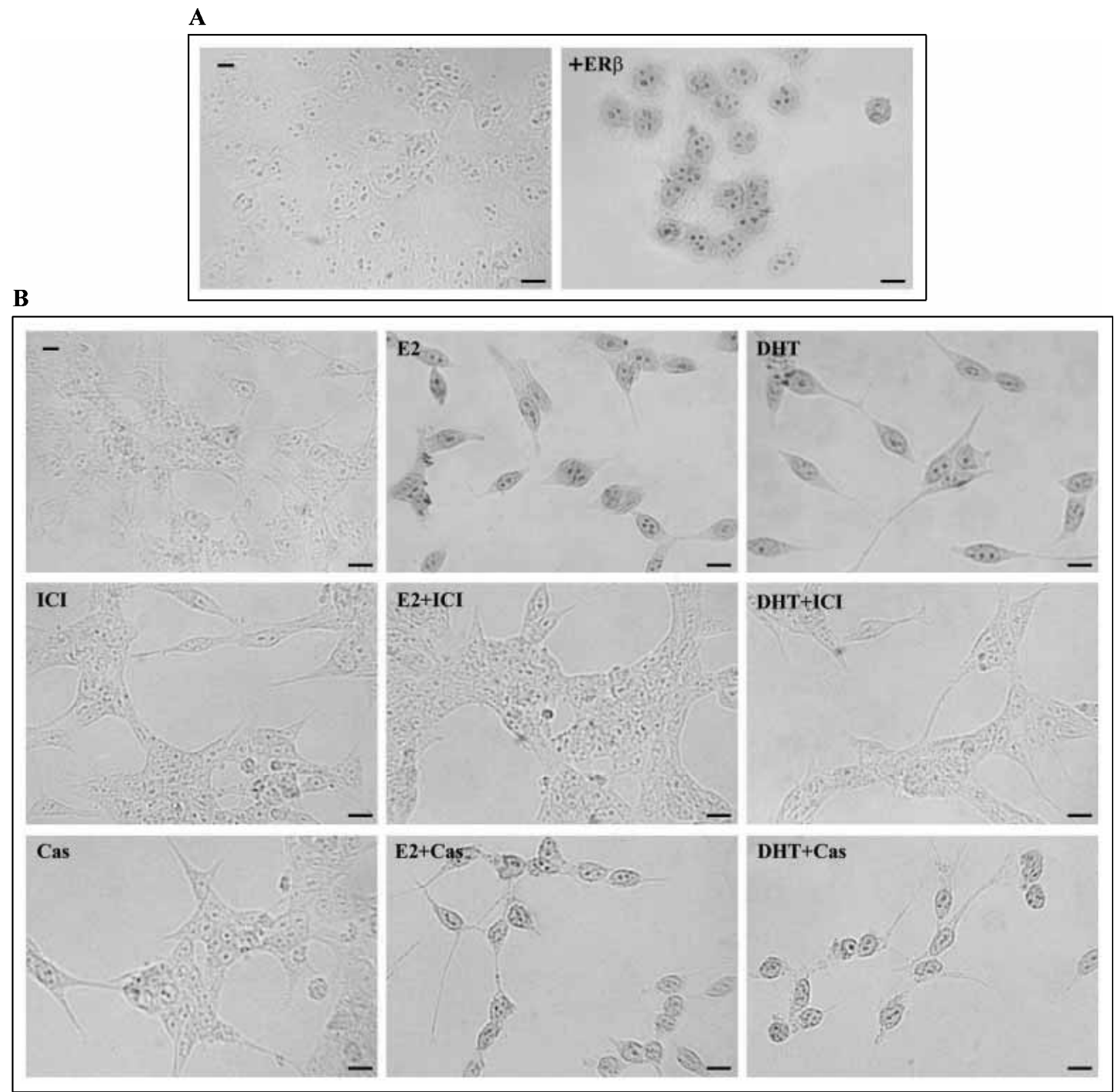

Figure 5 The nuclear compartmentalization of ER $\beta$ induced by E2 and DHT in LNCaP cells is inhibited by ICI 182,780 but not by casodex (Cas). (A) Steroid receptor negative HeLa cells were transfected with an empty vector $(-)$ or with an expression plasmid encoding $\operatorname{ER} \beta(+\mathrm{ER} \beta)$ and treated $1 \mathrm{~h}$ with $10 \mathrm{nM}$ E2 to verify the specificity of the antibody used. (B) LNCaP cells were treated with ethanol (-) or $10 \mathrm{nM}$ E2 and DHT and $1 \mu \mathrm{M} \mathrm{ICl} \mathrm{182,780} \mathrm{and}$ Cas for $1 \mathrm{~h}$. Each experiment is representative of at least 10 tests. Bar represents $5 \mu \mathrm{M}$.

proliferation by ICI 182,780, which displayed no effect on the transcriptional activation of AR by hormones, prompted us to utilize a different method to analyse the role of $\operatorname{ER} \beta$ in the growth of these androgen-responsive prostate cancer cells. Hence, we transfected LNCaP cells with an ER $\beta$ antisense expression vector to block expression of ER $\beta$. The ER $\beta$ antisense construct effectively reduced $\operatorname{ER} \beta$ protein concentrations and inhibited only the growth of LNCaP cells stimulated by E2 or DHT (Fig. 7B, C), providing further evidence for an involvement of $\operatorname{ER} \beta$ in the proliferative 
(A)

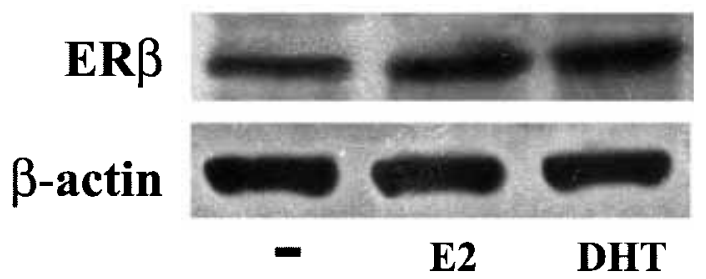

(B)

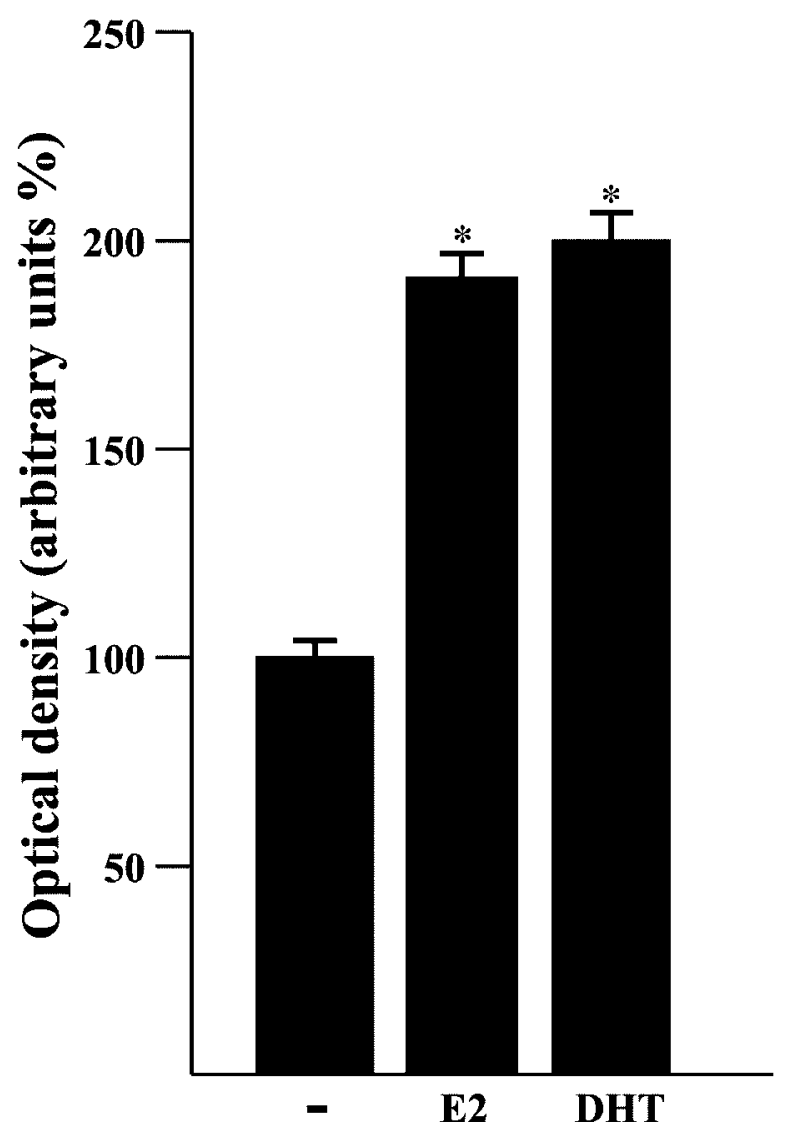

Figure 6 Immunoblot of ER $\beta$ from LNCaP. (A) Cells were treated for $24 \mathrm{~h}$ with ethanol (-) or with $10 \mathrm{nM} \mathrm{E2}$ and $\mathrm{DHT}$, and $70 \mu \mathrm{g}$ total protein lysate was used per lane to evaluate ER $\beta$ protein levels. $\beta$-Actin served as loading control. (B) Quantitative representation of data of three independent experiments including that of $(A)$ after densitometry and correction for values of cells treated with vehicle. ${ }^{\star} P<0.05$ compared with ethanol alone $(-)$.

response to both hormones. Of note, the expression of AR was not changed by the $\operatorname{ER} \beta$ antisense expression plasmid (Fig. 7B).

\section{Discussion}

Our results provide evidence for a proliferative role of $\mathrm{ER} \beta$ in LNCaP cells, which have been used extensively as a model for androgen-responsive prostate cancer (Webber et al. 1997). These cells express a point mutation of the AR that allows it to respond to both androgens and oestrogens. Both types of hormone are also able to stimulate the proliferation of these cells and, therefore, it had been assumed that the proliferative stimulus of oestrogen was solely attributable to its ability to activate the AR mutant. To our surprise, either antagonist is able to block the proliferative stimulus of either steroid. These and additional findings call for a fundamental reinterpretation of the oestrogenic stimulation of LNCaP cell proliferation. We conclude that oestrogens stimulate the proliferation of these cells by activating both $\operatorname{ER} \beta$ and AR. This suggests that the evaluation of receptor status in prostate tumours should include $\operatorname{ER} \beta$ in addition to $\mathrm{AR}$. At least for a subset of $\mathrm{AR}^{+} \mathrm{ER} \beta^{+}$prostate tumours, antioestrogen treatment such as ICI 182,780 should be considered in addition to androgen ablation therapies.

We have shown that the mutated AR T877A and even ER $\beta$ were transactivated by DHT and E2 both in LNCaP cells and in HeLa cells that were engineered to express both receptors. Interestingly, such a promiscuous response of ER $\beta$ recalls previous studies on the role of androgens as potential agonists for ER $\alpha$ (Ekena et al. 1998, Maggiolini et al. 1999), indicating, furthermore, that the two ER isoforms exhibit similar liganddependent AF2 activity (Cowley \& Parker 1999, McInerney et al. 1998). In contrast, the AF1 response of $\mathrm{ER} \beta$ is weaker than that of $\mathrm{ER} \alpha$ (Cowley \& Parker 1999) and, as a consequence, $\operatorname{ER} \alpha$ activation greatly exceeds that of $\operatorname{ER} \beta$ when both AF1 and AF2 are active in a particular cell or promoter context (McInerney et al. 1998, Hall \& McDonnell 1999, Delaunay et al. 2000). As observed in the present study, E2 and DHT cross-activated ER $\beta$ and the mutated AR; however, the transcriptional activity of each receptor could be reversed only by the specific inhibitors ICI 182,780 and casodex, respectively. This reinforces the concept previously proposed (Yeh et al. 1998) that the interaction between the agonist/antagonist receptor complex and cofactors may be essential for steroid hormone function and selectivity. Of 


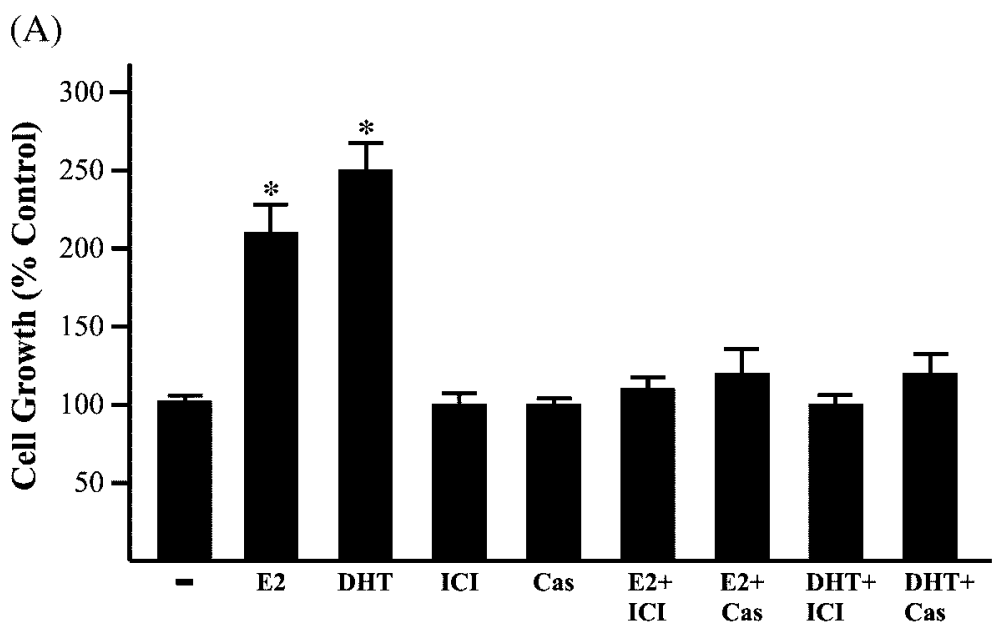

(B)
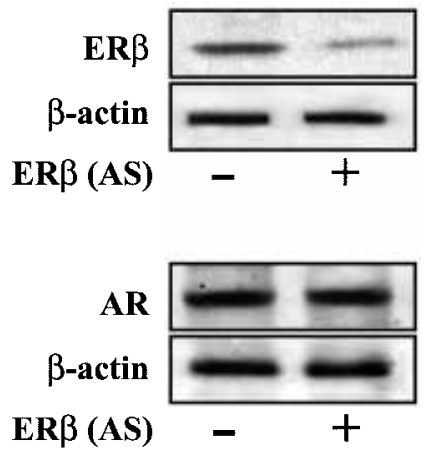

(C)

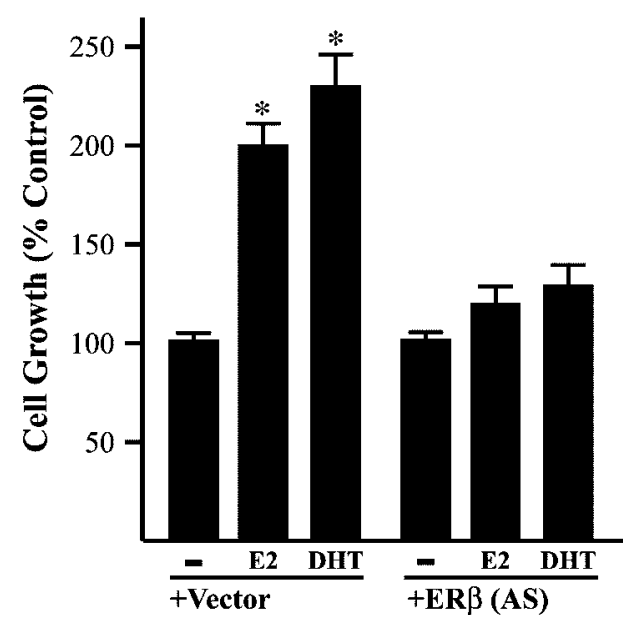

Figure 7 The proliferative effects of E2 and DHT on LNCaP cells are reversed by $\mathrm{ICl} 182,780$, casodex (Cas) and ER $\beta$ antisense (AS). (A) $10^{4}$ cells were seeded in 24-multiwell plates and after $24 \mathrm{~h}$ of serum deprivation the medium was changed with $0.1 \%$ charcoal-stripped FCS. At this point cells were treated with ethanol (-), $10 \mathrm{nM}$ E2 and DHT, $1 \mu \mathrm{M} \mathrm{ICI} 182,780$ and Cas. Medium and treatments were renewed every day for 3 days and the next day the cells were trypsinized and counted. The growth response is expressed as percentage of cells after treatments with respect to those treated with ethanol alone used in the same volume as for treatments. (B) Immunoblotting of ER $\beta$ and AR in LNCaP cells transfected with ER $\beta$ antisense. Protein expression was evaluated on the day of the cell count. (C) Proliferation of LNCaP was assayed as above, except that cells were transfected with the empty vector or ER $\beta$ antisense before treatments. Each data point represents the mean \pm S.D. of three independent experiments performed in triplicate. ${ }^{*} P<0.05$ compared with ethanol alone $(-)$.

note, ICI 182,780 failed to reverse the E2-induced transactivation of AR, but it blocked the proliferative stimulus exerted by E2. In addition, the results obtained using an antisense approach corroborated our conclusion from these pharmacological experiments. Thus $\mathrm{ER} \beta$ and $\mathrm{AR}$ are involved in hormone-stimulated proliferation of LNCaP cells, because each of the two antagonists, casodex and 


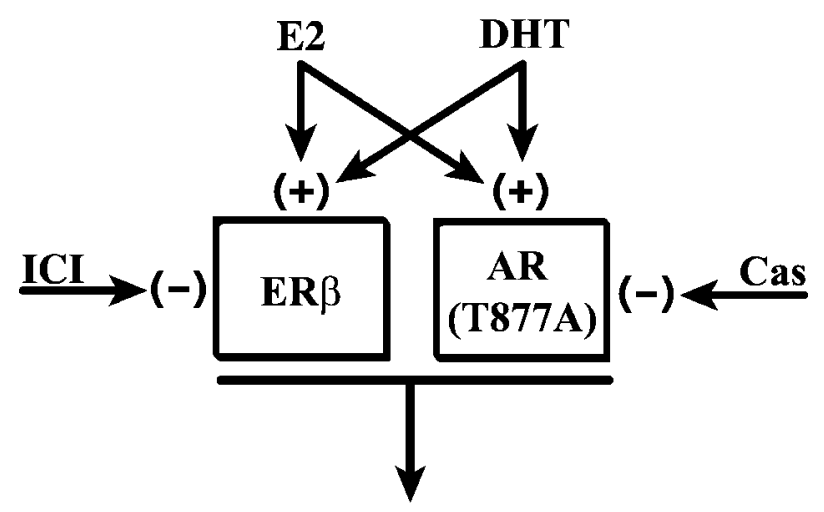

LNCaP Cell Proliferation

Figure 8 Schematic representation of hormone/ antihormone action in AR and ER $\beta$-mediated transcription that may lead to LNCaP cell proliferation.

ICI 182,780, repressed the activation of AR and $\mathrm{ER} \beta$ in a exclusive manner, but both compounds inhibited the proliferation of LNCaP cells (Fig. 8).

Prostate cancer is a leading cause of mortality and morbidity among men in Western countries (Parker et al. 1997, Wingo et al. 2001). After an initial stage characterized by androgen dependence and responsiveness to androgen deprivation, the disease exhibits no sensitivity to further hormonal manipulation in the ultimate progression (Garnick 1993, Catalona 1994, Klocker et al. 1994). The AR mutation T877A, characteristic of LNCaP cells, has also been found in prostatic tissue from cancer patients (Suzuki et al. 1993, Kuil \& Brinkman 1996). This and other mutations that alter the AR ligand-binding specificity and hence confer responsiveness to different compounds including oestrogens (Veldscholte et al. 1990, Culig et al. 1993, Elo et al. 1995, Tan et al. 1997, Maggiolini et al. 2002) may provide a potential mechanism by which prostate cancer cells escape the effects of antiandrogen treatments. Nevertheless, the role played by oestrogens in prostate cancer remains controversial. In the stromal compartment of human and rodent prostates, their actions are believed to be mediated via ERa (Kirschenbaum et al. 1994, Ehara et al. 1995, Hiramatsu et al. 1996, Prins et al. 1998, Bonkhoff et al. 1999). The discovery of ER $\beta$ (Kuiper et al. 1997), its localization in the epithelial compartment of rodent prostates (Couse et al. 1997, Lau et al. 1997) and its expression in human malignant cells (Lau et al. 2000) have raised the possibility that oestrogens and antioestrogens could exert important biological effects through an ER $\beta$ signalling pathway. In line with these observations, our findings extend to androgen-responsive LNCaP cells results previously obtained with DU145 prostate cancer cells, which express only $\operatorname{ER} \beta$ and no ER $\alpha$. Although DU145 cells do not depend on added steroids for proliferation, ICI 182,780 severely inhibits their proliferation (Lau et al. 2000), suggesting that these cells require at least a basal ER $\beta$ activity. Of interest, recent studies have also demonstrated that the selective ER modulator, raloxifene, induces apoptosis of androgen-sensitive or -insensitive prostate cancer cells through an androgen-independent pathway (Kim et al. 2002a, b).

How do both oestrogens and androgens stimulate the proliferation of LNCaP cells? As stated above, we propose that either type of hormone activates both $\operatorname{ER} \beta$ and $\mathrm{AR}$, and that both steroid receptors are required for the proliferative stimulus. Our experiments do not address the question of whether these nuclear receptors function as ligand-activated transcription factors or act in combination with rapid non-genomic signalling, although the Src inhibitor PP2 was not able to block the response to hormones. In a previous study (Migliaccio et al. 2003), cross-talk between steroid receptors was reported to regulate the non-genomic proliferative pathways of different steroids. In LNCaP cells, either E2 or the synthetic androgen R1881 induced the assembly of a ternary complex of AR, ER $\beta$ and Src, stimulated the Raf-1/Erk signal transduction cascade, and triggered entry into S-phase (Migliaccio et al. 2000). ICI 182,780, casodex and an inhibitor of Src prevented assembly of this complex and nongenomic signalling elicited by either agonist. These findings are compatible with a role for nongenomic signalling in driving the proliferation of LNCaP cells. However, sustained hormonestimulated proliferation is likely to be more than entry into the first S-phase, as stimulated by non-genomic signalling. A large number of studies support a contribution of transcriptional effects (Beato 1989, Beato et al. 1996, Yeh \& Chang 1996). New genetic and pharmacological tools will have to be developed if the contributions of genomic and non-genomic pathways mediated by endogenous steroid receptors are to be elucidated.

Progressive loss of ER $\beta$ expression has been found in prostatic hyperplasia and, to a greater 
extent, in invasive cancer (Horvath et al. 2001). A similar pattern was observed after the development of breast and colon tumours (Enmark et al. 1997, Foley et al. 2000). Interestingly, prostate tumours that retain $\operatorname{ER} \beta$ appear to be associated with a greater rate of relapse (Horvath et al. 2001). These data imply that the role of $\operatorname{ER} \beta$ in regulating the growth of different tumours is complex and that further studies are needed to clarify the link between ER $\beta$ and cancer. As it concerns prostate carcinoma, the presence of functional $\operatorname{ER} \beta$ may represent a potential target for treatment with antioestrogens.

\section{Acknowledgements}

D P was supported by the Swiss National Science Foundation, Krebsforschung Schweiz, and the Canton de Genève. This research was supported by 'Lega italiana per la lotta contro i tumori'.

\section{References}

Beato M 1989 Gene regulation by steroid hormones. Cell $\mathbf{5 6}$ 335-344.

Beato M, Herrlich P \& Schutz G 1995 Steroid hormone receptors: many actors in search of a plot. Cell $\mathbf{8 3} 851-857$.

Beato M, Chavez S \& Truss M 1996 Transcriptional regulation by steroid hormones. Steroids 61 240-251.

Berry M, Nunez AM \& Chambon P 1989 Estrogen responsive element of the human $\mathrm{pS} 2$ gene is an imperfectly palindromic sequence. PNAS 86 1218-1222.

Bonkhoff H, Fixemer T, Hunsicker I \& Remberger K 1999 Estrogen receptor expression in prostate cancer and malignant prostatic lesions. American Fournal of Pathology 155 641-647.

Brolin J, Skoog L \& Ekman P 1992 Immunohistochemistry and biochemistry in detection of androgen, progesterone and estrogen receptors in benign and malignant human prostatic tissue. Prostate 20 281-295.

Bunone G, Briand PA, Miksicek RJ \& Picard D 1996 Activation of the unliganded estrogen receptor by EGF involves the MAP kinase pathway and direct phosphorylation. EMBO 15 2174-2183.

Carruba G, Pfeffer U, Fecarotta E, Coviello DA, D'Amato E, Lo Castro M, Vidali G, Castagnetta L 1994 Estradiol inhibits growth of hormone non-responsive PC3 human prostate cancer cells. Cancer Research 54 1 190-1193.

Castagnetta L, Miceli MD, Sorci CM, Pfeffer U, Farruggio R, Oliveri G, Calabro M \& Carruba G 1995 Growth of LNCaP human prostate cancer cells is stimulated by estradiol via its own receptor. Endocrinology 163 2309-2319.

Catalona WJ 1994 Management of cancer of the prostate. Nerw England Fournal of Medicine 331 996-1004.

Couse JF, Lindzey J, Grandien K, Gustafsson JA \& Korach KS 1997 Tissue distribution and quantitative analysis of estrogen receptor- $\alpha \mathrm{ER} \alpha)$ and estrogen receptor- $\beta(\mathrm{ER} \beta)$ messenger ribonucleic acid in the wild-type and $\mathrm{ER} \alpha$ knockout mouse. Endocrinology 138 4613-4621.
Cowley SM \& Parker MG 1999 A comparison of transcriptional activation by $\mathrm{ER} \alpha$ and ER $\beta$. Fournal Steroid Biochemistry and Molecular Biology 69 165-175.

Culig Z, Hobisch A, Cronauer MV, Cato ACB, Hittmair A, Radmayr C, Eberle J, Bartsch G \& Klocker H 1993 Mutant androgen receptor detected in an advanced-stage prostatic carcinoma is activated by adrenal androgens and progesterone. Molecular Endocrinology 7 1541-1550.

Delaunay F, Pettersson K, Tujague M \& Gustafsson JA 2000 Functional differences between the amino-terminal domains of estrogen receptors $\alpha$ and $\beta$. Molecular Pharmacology 58 584-590.

Ehara H, Koji T, Deguchi T, Yoshii A, Nakano M, Nakane PK \& Kawada Y 1995 Expression of estrogen receptor in diseased human prostate assessed by non-radioactive in situ hybridization and immunohistochemistry. Prostate 27 304-313.

Ekena K, Katzenellenbogen JA \& Katzenellenbogen BS 1998 Determinants of ligand specificity of estrogen receptor $\alpha$ : estrogen versus androgen discrimination. Fournal Biological Chemistry $\mathbf{2 7 3}$ 693-699.

Elo JP, Kvist L, Leinonen K, Isomaa V, Henttu P, Lukkarinen O \& Vihko P 1995 Mutated human androgen receptor gene detected in a prostatic cancer patient is also activated by estradiol. Fournal of Clinical Endocrinology and Metabolism 80 3494-3500.

Enmark E, Pelto-Huikko M, Grandien K, Lagercrantz S, Lagercrantz J, Fried G, Nordenskjold M \& Gustafsson JA 1997 Human estrogen receptor beta-gene structure, chromosomal localization and expression pattern. Fournal of Clinical Endocrinology and Metabolism 82 4258-4265.

Foley EF, Jazaeri AA, Shupnik MA, Jazaeri O \& Rice LW 2000 Selective loss of estrogen receptor $\beta$ in malignant human colon. Cancer Research 60 245-248.

Garnick MB 1993 Prostate cancer: screening, diagnosis and management. Annals of Internal Medicine 118 804-818.

Grigoryev DN, Long BJ, Njar VC \& Brodie AH 2000 Pregnenolone stimulates LNCaP prostate cancer cell growth via the mutated androgen receptor. Fournal of Steroid Biochemistry and Molecular Biology $751-10$.

Hall JM \& McDonnell DP 1999 The estrogen receptor $\beta$ isoform $(\mathrm{ER} \beta)$ of the human estrogen receptor modulates ER $\alpha$ transcriptional activity and is a key regulator of the cellular response to estrogens and antiestrogens. Endocrinology 140 $5566-5578$.

Hiramatsu M, Machara I, Orikasa S \& Sasano H 1996 Immunolocalization of oestrogen and progesterone receptors in prostatic hyperplasia and carcinoma. Histopathology 28 163-168.

Horvath LG, Henshall SM, Lee CS, Head DR, Quinn DI, Makela S, Delprado W, Golovsky D, Brenner PC, O'Neill G, Kooner R, Stricker PD, Grygiel JJ, Gustafsson JA \& Sutherland RL 2001 Frequent loss of estrogen receptor- $\beta$ expression in prostate cancer. Cancer Research 61 5331-5335.

Kemppainen JA \& Wilson EM 1996 Agonist and antagonist activities of hydroxyflutamide and casodex relate to androgen receptor stabilization. Urology 48 157-163.

Kim IY, Kim BC, Seong do H, Lee DK, Seo JM, Hong YJ, Kim HT, Morton RA \& Kim SJ 2002 Raloxifene, a mixed estrogen agonist/antagonist, induces apoptosis in androgen-independent human prostate cancer cell lines. Cancer Research 62 5365-5369.

Kim IY, Seong do H, Kim BC, Lee DK, Remaley AT, Leach F, Morton RA \& Kim SJ 2002 Raloxifene, a selective estrogen receptor modulator, induces apoptosis in androgen-responsive human prostate cancer cell line LNCaP through an androgen-independent pathway. Cancer Research 62 3649-3653.

Kirschenbaum A, Ren M, Erenburg I, Schachter B \& Levine AC 1994 Estrogen receptor messenger RNA expression in human benign prostatic hyperplasia: detection, localization, and modulation with a long-acting gonadotropin-releasing hormone agonist. Fournal of Andrology 15 528-533. 
Klocker H, Gulig Z, Kaspar F, Hobisch A, Eberle J, Reissigl A \& Bartsch G 1994 Androgen signal transduction and prostatic carcinoma. World Fournal of Urology 12 99-103.

Krongard A, Wilson CM, Wilson JD, Allman DR \& McPhaul MJ 1991 Androgen increases androgen receptor protein while decreasing receptor mRNA in LNCaP cells. Molecular and Cellular Endocrinology 76 79-88.

Kuil CW \& Brinkmann AO 1996 Androgens, antiandrogens and androgen receptor abnormalities. European Urology 29 (Suppl 2) 78-82.

Kuiper GG, Enmark E, Pelto-Huikko M, Nilsson S \& Gustafsson JA 1996 Cloning of a novel receptor expressed in rat prostate and ovary. PNAS 93 5925-5930.

Kuiper GG, Carlsson B, Grandien K, Enmark E, Haggblad J, Nilsson S \& Gustafsson J-A 1997 Comparison of the ligand binding specificity and transcript tissue distribution of estrogen receptors $\alpha$ and $\beta$. Endocrinology 138 863-870.

Kumar V, Green S, Stack G, Berry M, Jin JR \& Chambon P 1987 Functional domains of the human estrogen receptor. Cell $\mathbf{5 1}$ 941-951.

Lau KM, Leav I \& Ho SM 1997 Rat estrogen receptor- $\alpha$ and $\beta$, and progesterone receptor mRNA expression in various prostatic lobes and microdissected normal and dysplastic epithelial tissues of the Noble rats. Endocrinology $139424-427$.

Lau KM, LaSpina M, Long J \& Ho SM 2000 Expression of estrogen receptor (ER)- $\alpha$ and ER- $\beta$ in normal and malignant prostatic epithelial cells: regulation by methylation and involvement in growth regulation. Cancer Research 60 3175-3182.

Leav I, Merk FB, Ofner P, Goodrich G, Kwan PW, Stein BM, Sar M \& Stumpf WE 1978 Bipotentiality of response to sex hormones by the prostate of castrated or hypophysectomized dogs. Direct effects of estrogen. American Fournal of Pathology 93 69-92.

Leav I, Lau KM, Adams JY, McNeal JE, Taplin ME, Wang J, Singh H \& Ho SM 2001 Comparativies studies of the estrogen receptors $\beta$ and $\alpha$ and the androgen receptor in normal human prostate glands, dysplasia and in primary and metastatic carcinoma. American Fournal of Pathology 159 79-92.

Levine AC, Kirschenbaum A, Droller M \& Gabrilove JL 1991 Effect of the addition of estrogen to medical castration on prostatic size, symptoms, histology and serum prostate specific antigen in 4 men with benign prostatic hypertrophy. Fournal of Urology 146 790-793.

McInerney EM, Weis KE, Sun J, Mosselman S \& Katzenellenbogen BS 1998 Transcription activation by the human estrogen receptor subtype $\beta$ (ER $\beta$ ) studied with ER $\beta$ and ER $\alpha$ receptor chimeras. Endocrinology $1394513-4522$.

Maggiolini M, Donzè O, Jeannin E, Andò S \& Picard D 1999 Adrenal androgens stimulate the proliferation of breast cancer cells as direct activators of estrogen receptor $\alpha$. Cancer Research $\mathbf{5 9}$ 48644869.

Maggiolini M, Bonofiglio D, Marsico S, Panno ML, Cenni B, Picard D \& Ando S 2001 Estrogen receptor alpha mediates the proliferative but not the cytotoxic dose-dependent effects of two major phytoestrogens on human breast cancer cells. Molecular Pharmacology 60 595-602.

Maggiolini M, Vivacqua A, Carpino A, Bonofiglio D, Fasanella G, Salerno M, Picard D \& Andò S 2002. The mutant androgen receptor T877A mediates the proliferative but not the cytotoxic dose-dependent effects of genistein and quercetin on human LNCaP prostate cancer cells. Molecular Pharmacology 62 1027-1035.

Mawhinney MG \& Neubauer BL 1979 Actions of estrogen in the male. Investigative Urology 16 409-420.

Merk FB, Warhol MJ, Kwan PW, Leav I, Alroy J, Ofner P \& Pinkus GS 1986 Multiple phenotypes of prostatic glandular cells in castrated dogs after individual or combined treatment with androgen and estrogen. Morphometric, ultrastructural and cytochemical distinctions. Laboratory Investigation 54 442-456.
Migliaccio A, Castoria G, Di Domenico M, De Falco A, Bilancio A, Lombardi M, Barone MV, Ametrano D, Zannini MS, Abbondanza C \& Auricchio F 2000 Steroid-induced androgen receptor-oestradiol receptor $\beta$-src complex triggers prostate cancer cell proliferation. EMBO Journal $195406-5417$.

Migliaccio A, Castoria G, Di Domenico M, De Falco A, Bilancio A, Lombardi M, Bottero D, Varricchio L, Nanayakkara M, Rotondi A \& Auricchio F 2003 Sex steroid hormones act as growth factors. Fournal of Steroid Biochemistry and Molecular Biology $\mathbf{8 3}$ $31-35$.

Mosselman S, Polman J \& Dijkema R 1996 ER beta: identification and characterization of a novel human estrogen receptor. FEBS Letters 392 49-53.

Panet-Raymond V, Gottlieb B, Beitel LK, Pinsky L \& Trifiro MA 2000 Interactions between androgen and estrogen receptors and the effects on their transactivational properties. Molecular and Cellular Endocrinology 167 139-150.

Parker SL, Tong T, Bolden S \& Wingo PA 1997 Cancer statistics. CA: a Cancer Fournal for Clinicians 47 5-27.

Power KA \& Thompson LU 2003 Ligand-induced regulation of $\mathrm{ER} \alpha$ and $\mathrm{ER} \beta$ is indicative of human breast cancer cell proliferation. Breast Cancer Research and Treatment 81 209-221.

Pratt WB \& Toft DO 1997 Steroid receptor interactions with heat shock protein and immunophillin chaperones. Endocrine Revieres $\mathbf{1 8}$ 306-360.

Prins GS, Marmer M, Wodham C, Chang W, Kuiper G, Gustafsson JA \& Birch L 1998 Estrogen receptor- $\beta$ messenger ribonucleic acid ontogeny in the prostate of normal and neonatally estrogenized rats. Endocrinology 139 874-883.

Robertson JA, Farnell Y, Lindahl LS \& Ing NH 2002 Estradiol up-regulates estrogen receptor messenger ribonucleic acid in endometrial carcinoma (Ishikawa) cells by stabilizing the message. Molecular Endocrinology 29 125-135.

Sack JS, Kevin FK, Wang C, Attar RM, Kiefer SE, An Y, Wu GY, Scheffler JE, Salvati ME, Krystek SR, Weimmann R \& Einspahr HM 2001 Crystallographic structures of the ligand-binding domains of the androgen receptor and its T877A mutant complexed with the natural agonist dihydrotestosterone. PNAS 98 $4904-4909$.

Santagati S, Gianazza E, Agrati P, Vegeto E, Patrone C, Pollio G \& Maggi A 1997 Oligonucleotide squelching reveals the mechanism of estrogen receptor autologous down-regulation. Molecular Endocrinology 11 938-949.

Schulze H \& Claus S 1990 Histological localization of estrogen receptors in normal and diseased human prostates by immunocytochemistry. Prostate 16 331-343.

Skliris GP, Parkes AT, Limer JL, Burdall SE, Carder PJ \& Speirs V 2002 Evaluation of seven oestrogen receptor $\beta$ antibodies for immunohistochemistry, western blotting and flow cytometry in human breast tissue. Fournal of Pathology 197 155-162.

Suzuki H, Sato N, Watabe Y, Masai M, Seino S \& Shimazaki J 1993 Androgen receptor gene mutations in human prostate cancer. Fournal of Steroid Biochemistry and Molecular Biology 46 759-765.

Tan J, Sharief Y, Hamil KG, Gregory CW, Zang DY, Sar M, Gumerlock PH, White RWV, Pretlow TG, Harris SE, Wilson EM, Mohler JL \& French FS 1997 Dehydroepiandrosterone activates mutant androgen receptors expressed in the androgen-dependent human prostate cancer xenograft CWR22 and LNCaP cells. Molecular Endocrinology 11 450-459.

Taplin ME \& Ho SM 2001 The endocrinology of prostate cancer. Fournal of Clinical Endocrinology and Metabolism 86 3467-3477.

Tremblay GB, Tremblay A, Copeland NG, Gilbert DJ, Jenkins NA, Labrie F \& Giguère V 1997 Cloning, chromosomal localization and functional analysis of the murine estrogen receptor $\beta$. Molecular Endocrinology 11 353-362. 
Tsai MJ \& O'Malley BW 1994 Molecular mechanisms of action of steroid/thyroid receptor superfamily members. Annual Reviews of Biochemistry 63 451-486.

Veldscholte J, Ris-Stalpers C, Kuiper GG, Jenster G, Berrevoets C, Claassen E, van Rooij HCJ, Trapmann J, Brinkmann AO \& Mulder E 1990 A mutation in the ligand binding domain of the androgen receptor of human LNCaP cells affects steroid binding characteristics and response to antiandrogens. Biochemical and Biophysical Research Communications 173 534-540.

Webber MM, Bello D \& Quader S 1997 Immortalized and tumorigenic adult human prostatic epithelial cell lines: characteristics and applications. Part 2. Tumorigenic cell lines. Prostate 30 58-64.

Weihua Z, Makela S, Andersson LC, Salmi S, Saji S, Webster JI, Jensen EV, Nilsson S, Warner M \& Gustafsson JA 2001 A role for estrogen receptor beta in the regulation of growth of the ventral prostate. PNAS 98 6330-6335.

Wingo PA, Landis S \& Ries LAG 2001 An adjustment to the 1997 estimate for new prostate cancer cases. CA: a Cancer fournal for Clinicians 47 239-242.
Yeap BB, Krueger RG \& Leedman PJ 1999 Differential posttranscriptional regulation of androgen receptor gene expression by androgen in prostate and breast cancer cells. Endocrinology 140 3282-3291.

Yeh S \& Chang C 1996 Cloning and characterization of a specific coactivator, ARA70, for the androgen receptor in human prostate cells. PNAS 93 5517-5521.

Yeh S, Miyamoto H, Shima H \& Chang C 1998 From estrogen to androgen receptor: a new pathway for sex hormones in prostate. PNAS 95 5527-5532.

Zhou ZX, Lane MV, Kemppainen JA, French FS \& Wilson EM 1995 Specificity of ligand-dependent androgen receptor stabilization: receptor domain interactions influence ligand dissociation and receptor stability. Molecular Endocrinology 9 208-218.

Received in final form 16 February 2004 Accepted 27 February 2004 